\title{
Urban voids: identifying and optimizing urban voids potential as a revitalization source in enhancing developing countries' city income
}

\author{
Omnia Mamdouh Hashem * ${ }^{*}$, Sherine Mohy-Eldin Wahba and Tarek Ibrahim Nasr-Eldin
}

\author{
* Correspondence: \\ omniamamdouh2011@yahoo.com \\ Department of Architecture, Faculty \\ of Engineering, Cairo University, \\ Giza, Egypt
}

\begin{abstract}
This study attempts to remedy the issue of urban voids, which are one of the possible choices for extra interactive spaces. As a city with a great civilization history, Egypt is also home to many urban voids, mainly buffer zones. This generates the research problem that urban voids result from managing isolated planning sites irrespective of the context and away from the community. Few studies tackled the impact of public spaces on city life; they were mainly theoretically oriented and focused on piazzas without highlighting other spaces or conducting empirical investigations. The study determines that voids could be a testing ground to establish a framework of how these spaces can be reused. Revitalizing urban voids goal is to reconnect these useless spaces with context, achieve users' needs, integrate technologies with the space to revitalize the city, and increase its income through combining theoretical findings, empirical study, and questionnaires, which generate a framework that helps the planners and designers in developing urban voids and maximizing its efficiency. Currently, adaptive redesign is a hot topic to discuss, and this may be the moment to realize that following the updated design components, meeting community needs, and using technology will always reinvigorate the void.
\end{abstract}

Keywords: Urban public spaces, Urban voids, Design components, Users' needs, Technologies, Revitalization, Rebranding, City income

\section{Introduction}

In the last decades, many studies focused on urban public spaces focusing on piazzas and nodes without looking deeply for urban voids and leftover spaces and how to use them perfectly to be useful for the users and the city. The study provides a brief summary of the literature review, including the definition and idea of urban void [1]. Urban voids are spaces that have no function and are neglected, and they are mainly located between residential and commercial sectors with no clear explanation of their

(c) The Author(s). 2021 Open Access This article is licensed under a Creative Commons Attribution 4.0 International License, which permits use, sharing, adaptation, distribution and reproduction in any medium or format, as long as you give appropriate credit to the original author(s) and the source, provide a link to the Creative Commons licence, and indicate if changes were made. The images or other third party material in this article are included in the article's Creative Commons licence, unless indicated otherwise in a credit line to the material. If material is not included in the article's Creative Commons licence and your intended use is not permitted by statutory regulation or exceeds the permitted use, you will need to obtain permission directly from the copyright holder. To view a copy of this licence, visit http://creativecommons.org/licenses/by/4.0/. The Creative Commons Public Domain Dedication waiver (http://creativecommons.org/publicdomain/zero/1.0/) applies to the data made available in this article, unless otherwise stated in a credit line to the data. 
existence. When two or more projects are constructed, unplanned lost spaces are generated, such as vacant lots, empty areas, and uninhabited zones. These voids can be reused, revitalized, and managed to improve these spaces, especially in developing countries and satisfy users' needs who need valuable and pleasant spaces.

The importance of these voids must be determined to understand their potential contribution to a city's social, economic, and environmental qualities. They have a negative impact on the city's image, causes a bad visual image, and maybe a result of a lack of resources for strategic improvements [2].

The urban fabric of modern cities is transforming rapidly. A new view of how urban architecture is needed in order to satisfy the demands of the new community's users. In the sense of the built environment, urban voids are a critical value that must be used. Accordingly, void space has the power to become a tomorrow's fundamental pillar of the city [3]. After processing, incorporating and analyzing the planning of cities and their political, social, and economic transformation, there are four main categories of voids according to scale and ownership: the edges and buffer voids, infrastructural voids, transportation voids, and large scale plots [3].

It remains unclear why urban voids became a neglected space, and most of them turned into spaces for crimes and illegal uses, like spaces under bridges. After revitalization, the new image of urban voids becomes a vital space where many users like to go and meet together. These revitalized spaces provide a variety of activities as they are exposed on the main roads while people move everywhere. So it became a good source of attracting for people from different places passing by these spaces, maximizing the use of these spaces, increases the concern of the environment and its preservation through the use of new technological applications-all of that aid to rebrand cities and increase their income, especially in developing countries.

From perspective to the context, their design, appearance, and qualities are different. Some societies identify and strive to redevelop the unused potential of these spaces. A cities narrative will transform since these spaces are integrated into the urban fabric using new technological installations. While planning a city, it is hard to do so successfully without integrating technology into the space. It helps in the successful design and layout of urban voids, and incorporating it can boost creativity, connections, and trust with a given community. Technology is a tool that helps in the processes of designing more efficient projects. Therefore, the use and application of these technologies create innovative solutions to the different problems in the project. This propitiate the competitiveness of space, such as construction, landscape, management of the waste of the space, quality of the environment, systems of urban information with digital media, sustainable energy, and new materials applied to urban development and sustainable management of water.

Currently, the cities are coming to life in the technological world how these innovative cities become meaningful to people. The current development in technological public installations involves many new inventions espicially in materials and systems, which appeared in new dynamic and interactive spaces. Applying these installations required artists and designers to construct their work using these new systems and with a good understanding of human nature. It is no longer about carving stones and casting bronze; it is time to sculpture the interactive experience with public participation. With several design cases of interactive public installations, the study will present the design 
techniques and practices of these examples and try to present our attempts in evaluating the experience of interacting with the installations, such as the feeling of social connectedness and inclusion [1].

Therefore, the principles of revitalizing urban voids are combined and integrated with technological advances to create an interactive public space that makes people enjoy and interact together. Not only, creating enjoyable place where people can live, work, and play but also creating sustainable places that reduces energy consumption, wastes, and saves time.

Leftover spaces are known for multiple needs, such as seasonal events, artworks, strategic urbanism, and looking for sustainability through new technologies. This research explained the different categories of urban voids in the city and proposes values of these voids for the city [4]. Practical observation of these spaces provides an engaging and thought-provoking project, not just on an esthetic dimension but also as a motivation for the further incorporation of urban voids in urban architecture using new technological installations.

The purpose of this research is to create a framework of the revitalization urban voids for efficient and flexible re-integration of urban voids into the urban realm by closely evaluating morphology, context, users' needs, technologies used, and its economic impact on the city through studies, investigations, and questionnaires and then explaining the new technological installations used to revitalize urban voids, attract more users, rebranding the city, and increasing city income taking 6th of October City a case study.

So, the goal is to identify, explain, and solve these urban voids that we have not described for the mainstream of the city, addressing the problem statement of our study to find and test a clear framework that defines the relation between urban voids design principles, users' needs, and technological installations and their impact on revitalizing the city and increasing its income.

\section{Methods}

Problem definition

Over the last decades, various discipline trends have set many studies dealing with urban public spaces, most of them concentrated on common urban space structures, such as nodes, squares, and gardens, without focusing intensely on urban voids, especially urban buffer zones and did not look for the impact of users' needs on the urban void spaces, leaving many void spaces neglected. So, the research problem is crystalized despite a profusion of data about urban public spaces. Still, there is no comprehensive framework that defines the relation between urban voids design components, user's needs, and technological installations and their impact on revitalizing the city. Moreover, what is the process that should be followed to apply this framework that makes effective and interactive space, even what constitutes better urban space to present a happy life, branding the city, and increasing its economic income.

\section{Research propositions and methodology}

A descriptive-analytical method was used to identify and study the various factors affecting generating a vibrant and active space and the impact of following users' needs in the space, as shown in Table 1. The expected results show some factors in a 
Table 1 Research methodology and the analysis of urban voids revitalization process, (ref. Author)

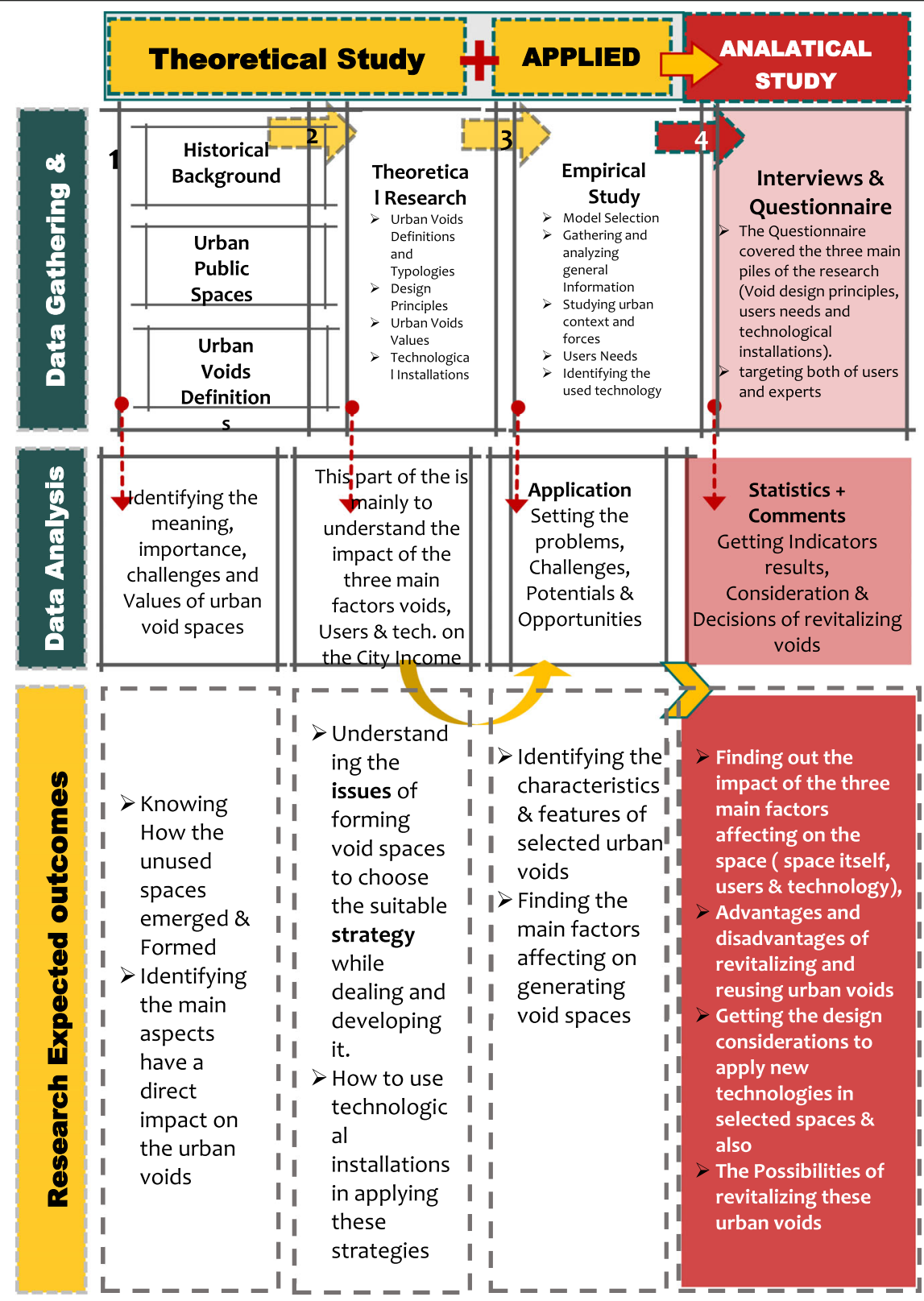

Recommendations \& Suggestions of Developing \& Revitalizing Urban Voids to Engage Them With City Urban Fabric, Attracting More Users and Increasing City Income

relationship with the qualities of the space and visitor's experience to generate a framework that link them together, taking in consideration the considerations while dealing with developing countries, such as vibrant, attractiveness, sense of security, technologies, landscaping, sustainability, and also other complementary factors.

This research tries to express the concepts of "urban space," "urban public space," and "urban voids." First, the theoretical foundation of urban voids design components. In the second phase, the idea of following "users' needs" and its relation with 
architecture and urban development are studied as well. Third, the importance of applying "technological installations" and new systems in revitalizing urban voids. And also the economic impact on the city after revitalizing these voids, see Fig. 1.

The research used the concept of "revitalization" to explore the validity of the proposals to engage the concepts of urban design principles with the technological dimensions of urban voids reflected in their significant importance for social life and increasing city income. The study also summarizes and highlights the theoretical studies, respectively four theoretical topics, in presenting the theoretical bases and empirical analysis carried out in each point. The four theoretical topics, namely, (1) the selected urban space, where the impact on users could be followed; that is, the "urban voids" and its "design components," (2) users' and their various needs and activities concerning urban design components, (3) technological installations and their applications on different elements of urban public space, (4) the relationship between these three main factors, the design considerations, and the economic impact on the city.

\section{Theoretical study}

In this section, an attempt made to define different urban spaces, urban public spaces, and urban voids. This part explains the presence of urban voids in cities. Then, the study focus on urban voids and their different definitions and typologies from different authors. They are discussing the factors affecting forming urban voids to understand more about these spaces. Moreover, studying voids values and the different uses, even formal or informal uses, followed by the global emergence of technological and sustainable development.

\section{Definitions of urban spaces}

\section{Urban space}

According to Habermas, the principle of urban space is a cultural symbol, which emerged from the contrast between the government, community, and local economies and the integration of modern conceptions of private property. It seems there is a vibrant and mutually beneficial relationship between urban public space and social life, resulting in new contexts of publicity that often needs different forms of space [5].

Urban open spaces are also defined in a much more positive perspective since they reflect vital components of economic growth and prosperity, increasing the values of

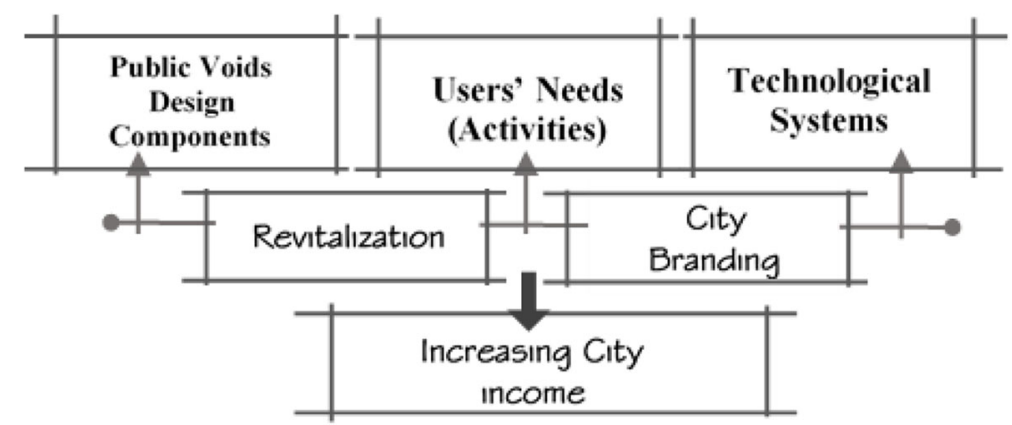

Fig. 1 Urban voids revitalization framework. Ref. Author 
surrounding properties and attracting local retail prosperity. In addition, the opportunity to serve community needs, integrate community groups and even encourage democracy and civic virtue, all of that has often been defined as publicly accessible spaces [6]. A variety of research studies have found that the emerging movement of urban public space design with commercial, recreation, and tourism components leads to the intensification of individual hedonism and relationship or public respect [7]. Moreover, Francis (2003) presented in his research the concept of urban open space as open spaces that are planned and constructed for activity and entertainment that are freely accessible [8]. In Lynch's understanding of it, this term "open" is used, specifically to the usability of space. He states that the efficiency of open space is a vital consideration for public access [9].

\section{Urban public space}

Urban public spaces provide a shared benefit to diverse groups of society; to be specific, where people and groups of distinctive social, social, and financial structure, from distinctive ages, sex, and level of instruction, conventions, traditions, and foundations are together [10]. In urban planning, public space has historically been described as open spaces, meaning the streets, parks and recreation areas, plazas, and other publicly owned and managed outdoor spaces, as opposed to the private domain of housing and work [11]. According to Cresswell, urban areas are often rooted in the built environment, but come into being through reiterative social processes, such as neighborhood events [12].

Part of the public realm, public spaces, could be defined as the public faces of houses, the gaps between façades, the events taking place in and between these gaps, and the administration of these events, all of which are influenced by the operation of the houses themselves-the private realm [13]. As noted before, public space has been a vital feature of cities and urban culture. They give chances for gathering, socializing, amusement, celebrations, and challenges and demonstrations. Parks and other urban open spaces regularly work as gatherings for community inclusion and recovery, and they can offer assistance to make a sense of put and having a place for urban inhabitants. There are three primary components that form urban public space. They are the space itself, the surrounding building and the users of the space, see Fig. 2. These three components are affected by the following: physical highlights, form an estimate of forces, space character, and behavior of users, which reflect social arrange and flows of human development, which discovers their reflection within the sociometric format of a given put [14].

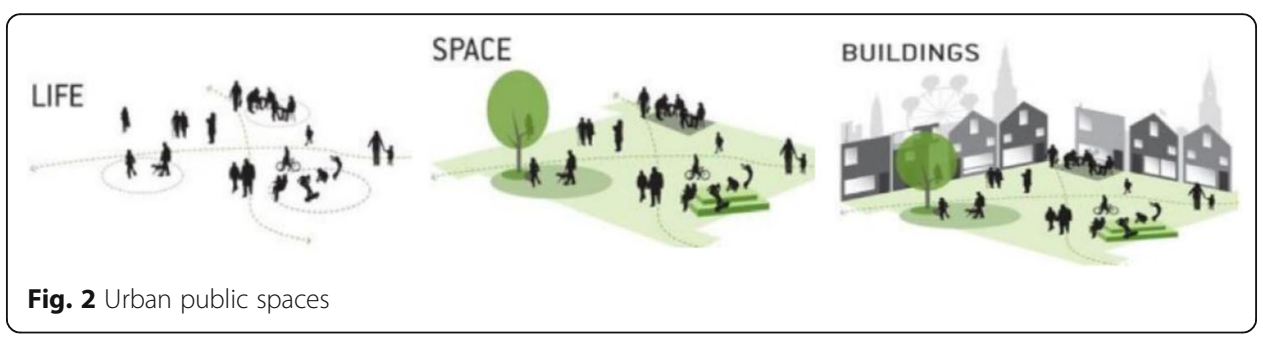




\section{Urban voids}

Urban voids are areas that rupture the city urban fabric. These spaces are often overlooked or ignored spaces in people's minds. These spaces are also the outcome of designing away from the community needs, as there is a result of managing remote planning sites irrespective of the built environment and poorly designed [15]. Research noted that void, distance, lost, and urban voids are the most used terminology for these spaces. The following meanings were drawn from the MerriamWebster dictionary to explain their importance before the theoretical definitions are studied [3]:

1. Void means "nothing contained," "vacant space," "not used," "not occupied." "The quality or state of stand without anything."

2. Gaps are a "split in space," a crack in continuity.

3. Lost is described as "hidden or neglected during a process or operation," not given use of, "and" actually or spiritually damaged or destroyed.

4. Leftover described as "something that still exists and stays unused."

The difference between "open space," as defined in regulations for urban city spaces, and "public space" has discovered new declensions connected to group or individual public life, currently happening in centralized contexts as well as in peripheral areas or leftover spaces up to edge cities, capable of giving values and functions to neglected or abandoned places. As Vittorio Gregotti noted in his introduction to Casabella, all of these expressions explain the need to reuse these voids and generate interactive public space and its architectural definition in a new way [16].

Therefore, studying urban voids is essential as it is an important topic that has great value for built environment practitioners, especially developing countries, see Fig. 3.

\section{Urban voids}

\section{Definitions}

There are many different ways to define the term urban void. These ways related to the way they have been formed, their beginnings, their history, and the ability of development. The concept of urban voids would therefore include space and

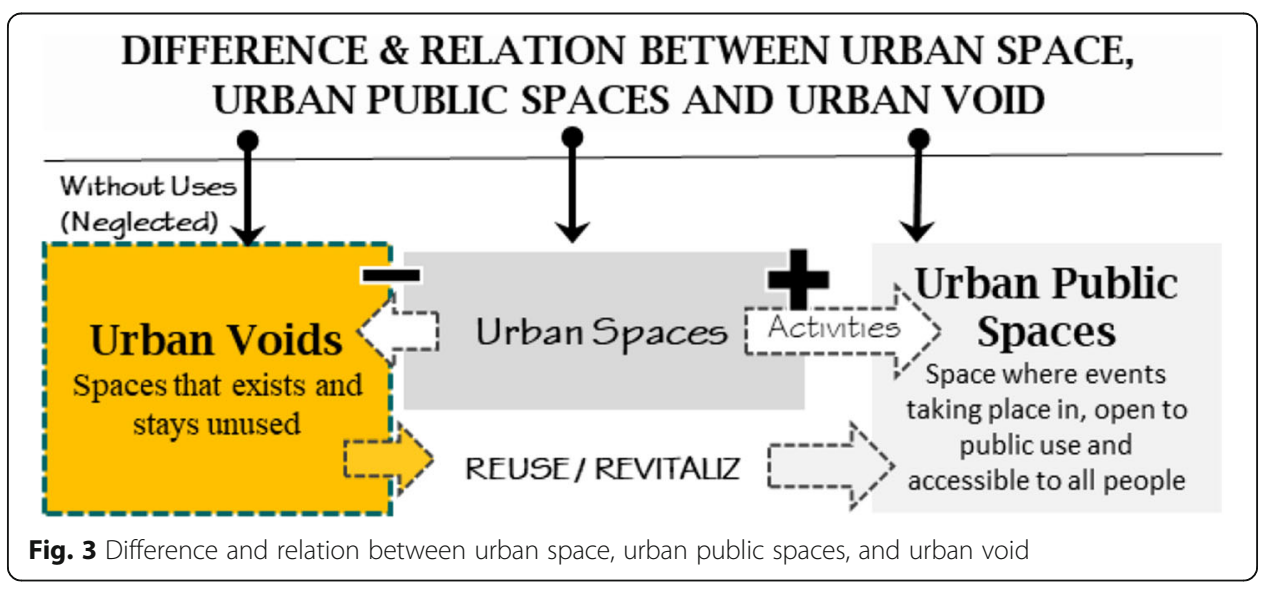


time. While reviewing the literature, the term of urban void, unoccupied areas, vague land, abandoned land, etc., tend to be confused [17]. In this research, the word urban voids refers to the lack of functions, lack of people, and lack of esthetic values in terms of the urban concept [18]. The voids of the city are also the spaces that divide the urban tissue and leave it incomplete, which are either public or private at the boundary. This also signifies vacancies in urban areas, which are then vacated and neglected.

According to Trancik [15], urban voids were identified as negative, empty, and no human interaction. This is commonly the case along railways, residential areas edges, underdeveloped roads, deserted military courts, and deserted industrial areas. Lynch [9] describes void spaces as neglected, useless, empty areas, and waste zones. These spaces generated by permanent uses that generally remain close to fixed projects such as (highways, railways, bridges,...). So, he discussed that voids are potential in the city that must be used [19]. Voids could be revitalized, reused, and relieved by making these spaces more flexible to meet all time requirements even in functions or in meeting different users' needs.

He highlighted two categories of urban voids: void spaces for function, such as remaining undefined areas, and spaces for particular uses are the other type. Cerleau (1988) states that void spaces are generated because government distributes various areas of the city and denies any areas that are not covered by it. In the metropolis, these places are now blind and forgotten. He also focused on the importance of reusing these voids, which can combine the city and have a vital role in the recreational functions of these spaces.

\section{Brief history of urban voids}

Due to its negative influence on cities, the problem of urban voids and neglected spaces has become a significant issue in the last decade since the beginning of the twenty-first century. Urban voids are becoming more widespread, and the importance of repurposing and transforming these voids is expanding [20]. In the 1950s and 1960s, urban void spaces arose from the old city centers, which had many commercial and industrial activities that had relocated to the suburbs, leaving behind vacant spaces and abandoned structures in strategic locations within the city [21]. In the 1970s, especially in EU and US, the motivation in revitalizing and reusing urban voids and vacant lots increased. Informal organizations have sprung up to take advantage of these neglected and unused spaces. Since the 1980s, new public-private partnerships and strategies have established to reuse industrial zones and convert them into commercial and residential spaces. The processes of regeneration and rehabitation in the following decade engaged with urban voids and void spaces, and there were strategies to reconnect to the city context that connected to these activities [8].

Cairo has numerous void spaces, which has formed buffer zones that have fragmented the city's physical form. The resulting void spaces used for criminal activity, wastes, and parking garages, among other things. As a result, a case study of the leftover space in Egypt developed to highlight its potential for various community facilities. The parameters used to construct this analysis are based on revitalization criteria. 


\section{Different typologies of urban voids}

There are similarities between western cities and Egyptian cities. Still, there are also significant differences, attempting to compare these types of voids with the urban history of Egypt-taking into account the issue of the ability of urban voids-to relate to the public realm, which explains the different urban void types. After processing and incorporating, there are four main categories of voids according to scale and ownership [22]: Edge and buffer voids, infrastructural voids, transportation voids, and large scale plots (see Table 2).

\section{Urban buffer zones}

Urban buffer zone typology was selected to be studied because it is the most common type of voids in Cairo, especially in 6th of October City. Also, many projects have been built in this type of void recently. Therefore, most urban voids in 6th of October City are buffer zone types: desert, parking lots, or green space that separate between residential zones and main roads, explained in Fig. 4.

\section{Factors affecting on forming urban voids/buffer zones}

Typology as an idea is a focal point of the realm of urban design. While categorization relates to the "Study and Theory of Types and Classification Systems," the term "type" is vague. Typology as a term is critical when researching similarities and distinctions between objects or phenomena. For this reason, this study proposes a typology of vacant spaces to group together identical forms of space and distinguish the various spaces [3].

Table 2 The form of the four main categories of voids according to scale and ownership (ref. [22])

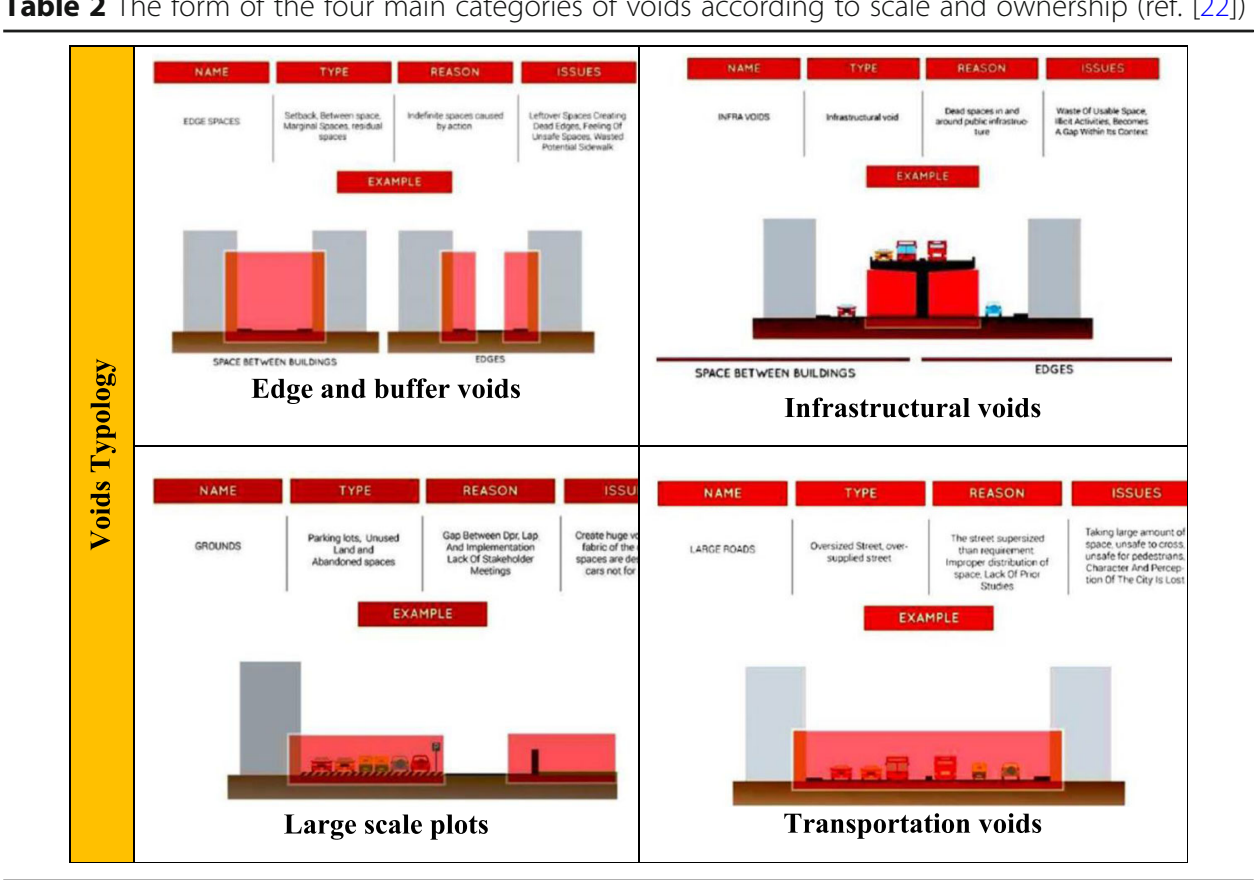




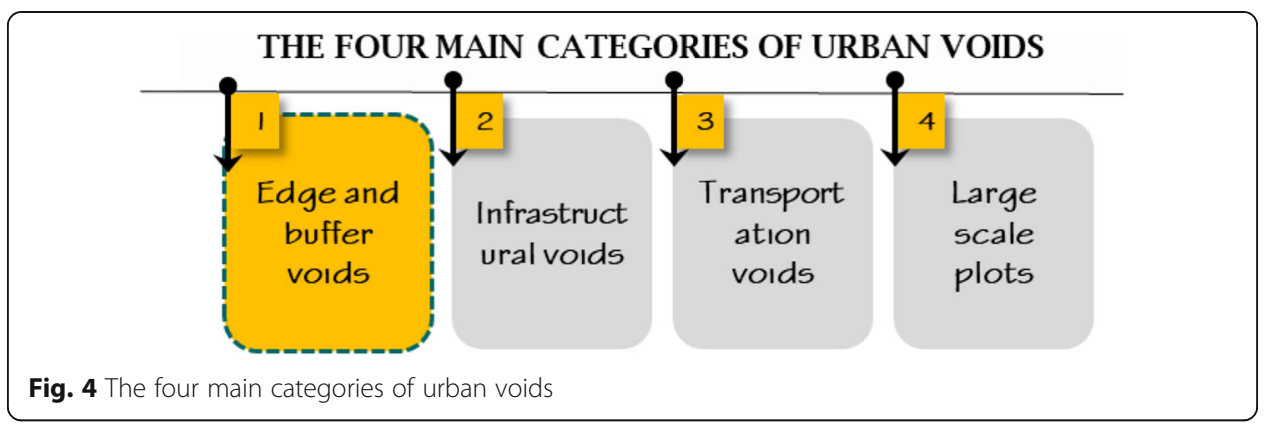

\section{Geographical factors}

Geographical forces affect the development of urban voids; they may be physical obstacles like the land that generate unshaped, unfamiliar spaces which are not used. There might be natural events that have led to the relocation of citizens of some spaces and turned into unused spaces or buildings without the use [23]. Some cities have their geological characteristics. Voids created when city planners and developers do not react to these geographical characteristics, leaving the space chaotic.

\section{Planning and design factors}

Voids are generated mainly through ineffective and inadequate planning procedures. These are actually built without knowing the fabric of the city due to designing in isolation. These can also be viewed using figure-ground theory in our cities that are most noticeable [22]. Moreover, the new revolution in urban design is not appropriate for planning all of these cities. This is the explanation for having separate buildings between parking lots and highways [19].

\section{Functional factors}

The function of the space or its surrounding area is one of the most common factors that generate urban voids. Post-industrial resources include closed industrial sites, void spaces created under bridges, on the edges of highways, and abandoned railway lines. When a specific space is not used efficiently, the space becomes defunct [22].

\section{Political factors}

Wars negatively affect the region's built environment, which influences generated void spaces. Another political aspect is faulty decisions, ineffective land management, and effective collaboration between decision-makers and stakeholders [24].

\section{Economic factors}

Urban gaps are the outcome of ages of interlinking between economic transitions and urban developments. Land value in the communities is decreasing, and its value is declining. Rental properties do not have enough profit for investors to pay taxes to manage their facilities and meet their expenses, contributing to the abandonment of owners of these no longer viable facilities [25]. In addition, economic disinvestment and increased taxes significantly affect urban spaces, commercial, and tourism operations. 


\section{Cultural factors}

Technological advancement and economic growth and the population moved to the country contributed to dominance and increasing use of cars. This condition has limited the usage of the downtown area that has become an infamous area, making it an ideal place for urban empty spaces to appear [15].

\section{Values of urban voids \\ Social value}

Urban voids reflect an excellent opportunity to give the society in the city urban voids a variety of social opportunities and values that would provide the ability to compensate for the lack of open spaces faced by many communities, especially cities with population density. Open spaces play an essential role in achieving social advantages that enable people to behave and strengthen social relations, engaging communities. It facilitates various uses, purposes, and events of social cultures, such as parks, small gardens, neighborhood gardens, and public piazzas [26]. Small urban voids can also give the ability to form a network of interconnected spaces capable of offering various levels of connections and different types of uses [27].

\section{Environmental value}

Urban voids may have many environmental advantages, increasing the quality of life in communities. These underutilized areas can use as transportation technologies and an ecological advantage to help the environment develop [8]. Furthermore, urban voids may play an important role in stormwater management. Many cities in the USA, including Philadelphia, Cleveland, and Milwaukee, have recently developed a wastewater management plan that involves urban voids [28].

\section{Economic value}

Urban voids also can offer a range of strategic economic advantages to a community on many sides. It significantly impacts the economy to strengthen the city economic structures, contributing to further spending and employment opportunities. Also, they may include low-cost working spaces and areas for transient use, making them urban catalysts for city growth [21]. Such voids will also create resources for small local economic sectors and assist with economic development. These voids also create excellent chances for local societies to raise their income via small-scale ventures such as retail opportunities through kiosks, shops, and markets. Moreover, job vacancies and skill improvement are also available [29].

\section{Historical value}

At the level of historical significance, these spaces are an essential part of the city and represent its development over time. Urban voids and empty buildings have a clear connection to city history; repurposing these spaces while keeping in mind the city's history helps preserve the city's historical memory, identity, and character. 


\section{Cultural value}

Urban voids provide a fantastic chance to enhance and promote cultural activities in the city from a cultural perspective. As a result, redesigning urban voids as cultural spaces can promote a creative atmosphere while also adding character and individuality to a community. In addition, it can create a temporary occupancy to allow for arts uses and modify existing structures to accommodate new cultural uses [24].

\section{Visual and esthetic values}

Urban voids are gap points in the urban tissue that disturb the urban context and are incomplete. These inefficient spaces have a negative impact on the city's visual appearance and the connectivity of its urban structure. Furthermore, it decreases the economic worth of current assets [23].

\section{Applied study}

Urban voids revitalization in developing countries/Egypt

Urban voids provide significant potential in enhancing city economy, especially in spaces next to main road urban voids. These spaces are classified as useless voids in the city. However, they are in a critical and essential location [30]. In Egypt, especially in new cities, many projects tried to use these voids for the most effective engagement with the surrounded communities. The government recognized the importance of these spaces and tried to find the various components to redevelop and revitalize such voids.

In Egypt, the government realized that many cities in the modern era have recently been suffering from urban development problems due to rapid urbanization, increasing population, and economic crises, affecting the cities quality of life. On the other hand, there are many vacant urban spaces in these cities, which formed for many natural, historical, and economic reasons. These unused spaces have adverse effects on the community and the urban fabric in which it is located. Despite the negative impact of these voids on the city, they provide great opportunities and possibilities for urban development and are considered among the potential resources for city redevelopment. So, the government worked on reusing these voids to enhance the city image and increase its income. This is achieved through programs to reuse the vacant spaces integrated with the government development strategies of the city. Responsible partners and stakeholders understood the significance of these voids in our cities and each community user requirements. They provided economic resources for renovation by the public or private sectors. It is essential to establish the strategy for the revitalization of urban voids [31].

In new cities, urban voids occupy a wide range of spaces in various locations; these locations sometimes are unique for the development process because of their contextual potential as waterfronts, central business districts, or locations near major main roads and transportation axis in the city. All of that offer excellent revitalization opportunities; as a result, a key aspect of the success of redevelopment of these sites is the location. This research aims to investigate all factors influencing the revitalization of urban void spaces in new communities in Egypt, like 6th of October City to contribute to a revitalization framework strategy for urban voids spaces and their surroundings. 
According to investigations, more clarity and information concerning city plans would be beneficial. For example, the majority of interviewees stated that there are no maps of the 6th of October depicting land that has been distributed, serviced, developed, or is still available (or at least not available to the public). Statistics on urban development indicators and wasted public investments, it is believed, should be produced and released [31].

\section{Challenges}

Urban void spaces can be both a source of opportunity and also a challenge for developers. Furthermore, there are numerous obstacles through the void spaces revitalization processes, such as the cost of construction and the maintenance strategy of these projects while revitalizing the space to follow the standards and keep the space suitable for users. These barriers can be summarized as follows:

1. Availability of urban public spaces: Public spaces became a vital part of the public domain of the informal old city; we live in a planned city where there is a lack of public space planning.

2. Lack of public engagement: There is a lack of public involvement from both sides of the government and the people. The role of the population in the process should therefore be essential to creating healthier societies, public spaces, and communities, and public engagement should be a priority.

3. The problematic ownership issue

4. The poor design strategy of public spaces: There is a discrepancy between people's expectations and design in the public spaces available locally. Local standards frequently forgotten, and architects are employed to design the public realm [28].

5. Lack of awareness among stakeholders

6. The specific requirement of constructions such as irrigation systems

7. Lack of policies and funding programs [3]

\section{Urban void requirements to be efficient}

Urban voids need to be reused and revitalized; it is necessary to make efficient use of voids in general based on the rules and regulations, and using green areas as a buffer has been a solution. However, the government believes now that, rather than abandoning current void areas, public projects can be a proper use while revitalizing these voids. Currently, most of the void spaces are being considered for transformation to increase city income.

When these spaces transition, it is important to remember that they are all various sizes and have distinct proprietors. Technology appears in some projects to achieve sustainability, but it is used on a small scale until now. It all depends on the proprietors and the estimated goals and whether it is willing to temporarily be used to make their site more appealing or a permanent use [3]. Converting urban void space into a public space has several advantages.

Some other benefits of revitalizing urban voids are listed below:

- Creating public green spaces that are easily accessible 
- They are creating public areas close to people's houses.

- Increase the number of job opportunities

- Free up space for commercial activities, which will create additional space for activities.

- Reduces pollution

\section{Urban voids revitalization: the framework of reusing urban voids and its positive impact on city income}

When it concerns to urban void spaces revitalization, many issues arise. For example, what principles must be followed to promote the advantages of revitalizing urban voids? Who will be in charge of using and evaluating these spaces? Then, who should be responsible in funding these projects? How do we deal with cross-departmental and cross-sectorial challenges, as well as achieve national policy? Also, what kind of technological installations should be used to achieve sustainability and fit the potential and capabilities of the city also? Urban voids revitalization is a complicated and difficult to predict issue [32]. In certain spaces, this issue is addressed by government programs that encourage investment.

Other countries deal with this issue, like Malmo city in Sweden, Zaragoza-Spain, Cleveland-USA, and Kwan Tong Bypass-Hong Kong. Most of these cities dealt with voids by establishing a suitable, efficient framework, and administrative system that allows for the private initiative while requiring personal responsibility and remedial action. As a result, a national strategy is essential to support the government in overcoming different concerns related to the reusing and revitalization process. Frameworks that engage all involved people and ensure regional strategies compatibility and complementarity with national strategies are in place.

According to Jackson, J.B [32]. and after studying urban voids features, gathering data about it and how to deal with them, the following three main pillars are the most important aspects to reuse and revitalize urban voids, besides involving all relevant stakeholders, see Fig. 5:

- Urban voids design components

- User needs and activities (social/cultural)

- Technological installations (environmental redevelopment)

\section{Urban voids design components}

Form and vitality Space form and scale play an essential role in making users feel comfortable and relax. Moreover, while revitalizing urban voids, a range of activities must be added and extend the hours of use to attract pleasant and vibrant public spaces. For example, a café, play facilities, or community apps will enhance the revitalized space. Adding some components in designing the space could increase its efficiency, maybe a large shade tree, sculpture or water feature, artwork, play, or performance area. Also, people, while watching events, prefer to gravitate to the edges of places to occupy them because they have good points of view for watching events both in space and in the immediate environment. Seat locations that provide an 


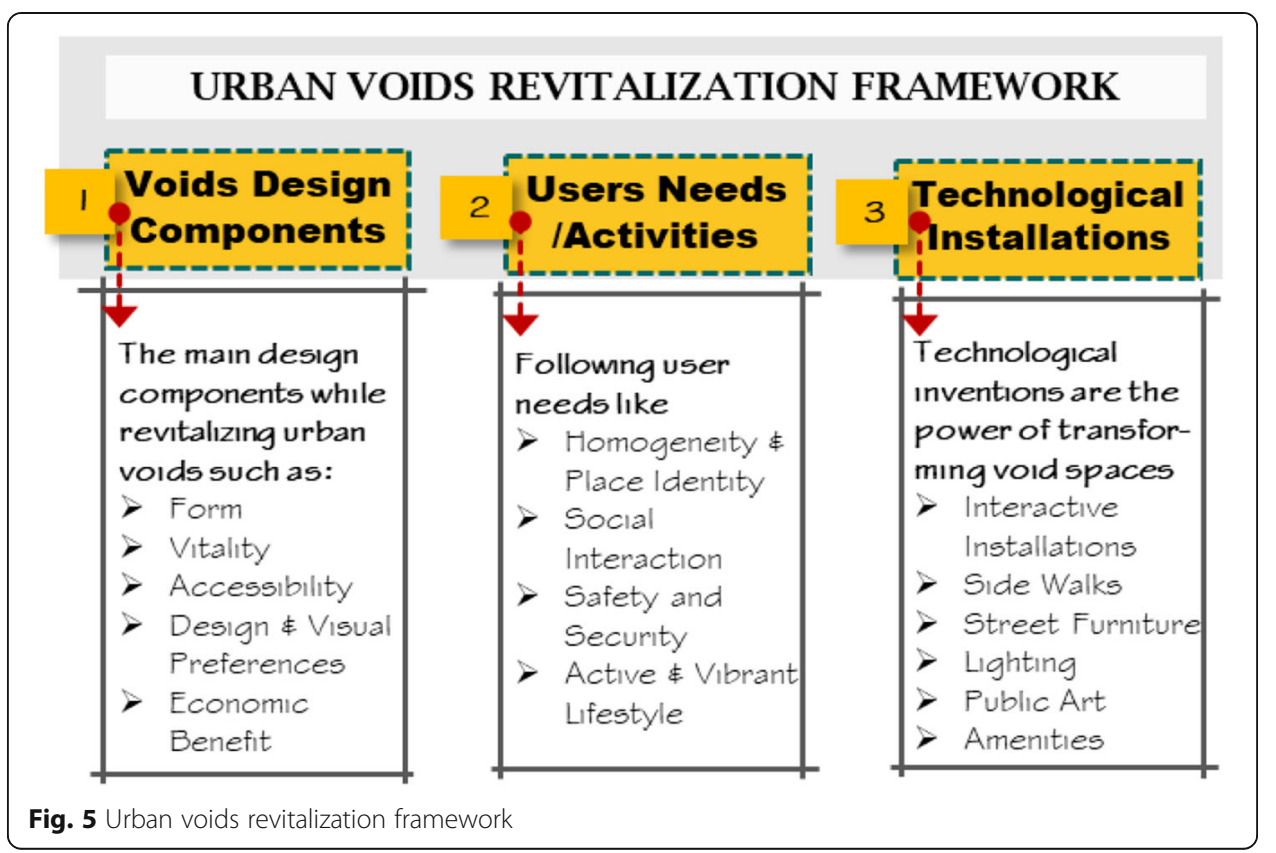

interesting viewpoint and views for visitors and the ability to watch passers-by. Popular areas are often those with good sightlines of the whole space and its entry points [33].

Accessibility While dealing with urban voids and following the revitalization process, it is necessary to ensure easy and secure access for all users through the urban void. This could be achieved through connecting the revitalized space to the pedestrian network around it. Also, the entrances must be located with direct views to the users. Continuous pedestrian pathways with straight, rational routes across the public space [33]. Moreover, it is essential to locate lighting to indicate paths and areas for night-time use and facilities for services in a designated zone away from the local pedestrian pathways and recreational facilities.

Design and visual preferences To support a strong sense of place and local character even in reflecting the contemporary urbanization like designing modern facades and adding new design features, and achieving uniqueness by attracting renowned designers, architects, and developers. Moreover, achieving richness of environment even in buildings or landscape is an essential issue by selecting planting and landscape elements that support the area's existing character or preferred future character. In addition, some successful projects that integrated locally relevant urban art that people can interact with is widespread and can draw people to space.

On the other hand, while developing urban voids, the boundaries of the space define the border without constructing high walls to separate the public space and private land. A minor shift in ground level can give the boundary description between public and private space to keep the visual connection between spaces. To ensure a comfortable and enjoyable space, its essential to start from the design stage of roads, seats, and essential locations to capture the winter sun and be shaded in the summer. Place trees to provide shade and protection for the season. 
Economic financial benefit/payback Urban voids revitalization increase city investment, a broader tax source, and job creation. Furthermore, by attracting as many prospective consumers as possible, offering the void spaces to all users increases the chances of marketing the site and develops connections between diverse uses [34].

Furthermore, because void spaces are typically found more in new cities and minority neighborhoods with high unemployment rates, redevelopment of these sites can relieve these issues. Some urban voids offer better redevelopment chances, usually where the fair market value is higher than the cost of redeveloping the space [35].

On the other hand, it is important to make sure the public spaces are appropriately used and maintained to keep it attractive for users and investors, as managing public spaces is the responsibility of a variety of organizations. In addition, there could be several departments and organizations with various roles in any public space, adding to the difficulty in development and management collaboration, so as to establish a management committee to oversee all aspects of public space management in a wide variety of public spaces. For a wide variety of people, create a schedule of ongoing events and activities. For example, markets, performances, exhibits, or neighborhood programs may include meetings and activities [33].

\section{User needs/activities}

Due to the economic and social evolution, new urban projects have evolved, especially in new cities, to suit the needs of users, which changed and required increasing quality of life away from the classical form of traditional compact cities. Many new spaces of the city are rearranging themselves in a non-linear manner due to new habits and societal needs. When they compare the classic compact city of the past with the modern city of today, the changes can be seen in all levels and since the CIAM, a new notion has emerged: urban area segmentation based on different uses.

Homogeneity and place identity The concept of filling these voids currently looks impossible, if not simply unacceptable. However, we must think of them as spaces with history, with their memories, and so working in developing them to give the city a new image. As discussed before, physical considerations are important but not the only component that must be followed to revitalize these voids. Determining user needs and working on achieving them is essential in determining how a city develops and revitalize. So, applying the required design components followed by achieving users' needs, reflected from the space identity, generate useful spaces for users and the city. New towns are emerging that accommodate their uses and requirements, are independent of the central city, and are focused on principles such as connectivity, efficiencies, and nonphysical aspects [36].

Social interaction (sense of community) The fundamental issue in appraising the revitalization process is measurability, particularly difficult to quantify in social elements such as esthetic values, security, and community involvement. This is why, while redeveloping urban voids, decision-makers must consider users' requirements and needs, engaging community members to promote the final product advantages to the community. The void space revitalization projects can create potential advantages for 
the area, such as health and recreation facilities, sports grounds, supply goods and different services, entertainment and recreation, social and educational facilities [37].

Safety and security Feeling safe in the space is an essential issue, even for adult people or for kids-for example, design play areas for children. Also, in the new projects, it preferred to find public restrooms, ATMs, and leisure equipment facilities that are situated in remote areas that feel dangerous and are avoided by consumers. From another view, security equipment-gates, walls, fences, 24-h security patrols, CCTV, and surveillance systems must be found.

Active and vibrant lifestyle Revitalized urban voids should encourage different uses (entertaining, work, sport, etc.) and promote events at the boundaries of the space. Different comfortable and enjoyable activities to suit different users like recreational and leisure activities.

\section{Technology/applying technological installations in urban voids}

Technology is an excellent gain for those working in urban design. It is tied with architecture years ago, as it is one of the most important forces affecting the urban spaces where most of them were formed and built before the new digital inventions. Technological inventions and new systems are the power and the engine of the transformations in urban spaces, incredibly while revitalizing urban voids. Transformations responded to social changes in political, social, cultural, technological, and economic alternations. Technology helping in rebranding the city through the integration with public spaces design principles.

Importance of using technology in revitalizing urban voids In the technological design of urban spaces, it is clear to lead environmental factors of spaces effectively. Architects aim to use as many natural components as possible, such as daylight, wind, rainwater, and greenery. As a result, the new architecture is frequently referred to as ECOTECHNOLOGY (Ecology + Technology). However, technology is not in opposition to nature; instead, it exists alongside and in combination with it is to maximize the use of environmental resources and provide comfort and health [38].

The current development in digital public installations involves many new carriers in material and technology, resulting in new dynamic and interactive forms that require the artists and designers to construct their work from a system view and a good understanding of human-system interaction. It is the time to design the interactive experience with public engagement, not only carving stones and casting bronze.

Therefore, the principles of revitalizing urban voids are combined and integrated with technological advances to create an interactive public space that makes people enjoy and interact together. Creating enjoyable places where people can live, work, play, and sustainable places reduces energy consumption, wastes materials, and saves time.

Technological installations in revitalizing urban voids On the other hand, there is much opportunity for transformation into a green space between spaces. This space is typically paved and non-permeable urban voids, but it could be turned into breathable 
space to reduce the solar heat gain and improve underground water resources. In addition, users will enjoy gardening to plant and develop, making it an excellent opportunity to take a step toward a more sustainable city. Piece-by-piece production, which includes repairing and modifying existing conditions, is also an option. Last but not the least, hi-tech installations such as electric vehicle charging stations and fuel cell cabins may be supported. Providing a charging station is a critical component of reviving the electric vehicle [1].

So that, in addition to the primary potentials, the architects and planners worked on how to design and generate attractive public space using new factors to encourage visitors to come to a specific place and enjoy it. These new developments refer to the new technological advances and how it affects the space to meet users' needs. As attracting more visitors and increasing tourism activity is a significant issue in increasing the cities economic impact, especially in developing countries.

Technological inventions could appear in void spaces like interactive installations, which are used mainly, see Fig. 6:

- Side walks

- Street furniture

- Lighting

- Public art and amenities

Applying technology in developing countries: economic impact and challenges As a result of an energy shortage, growing population, and increasing pollution, technological installations utilizing intelligent systems, new building materials, and innovations are emerging as a part of the solution to resolve these issues. Developing countries have recognized the value of including durability in their national agendas. However, accurate and perceived restrictions have limited their capacity to apply design. Therefore, technological innovation directly affects urban redevelopment, improved material quality, energy savings, and, as a result, sustainable architecture and environmental sustainability. Esthetics and human comfort are two other significant qualities that can be obtained through technology in revitalizing urban voids. On the other hand, the difficulties of using technological inventions in developing countries appeared and divided into five categories [39]:

\section{Government-related restrictions}

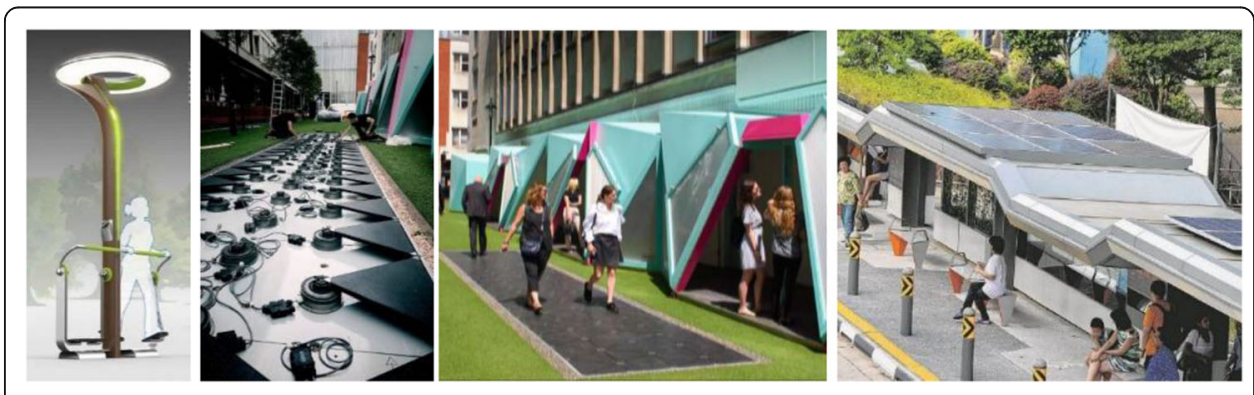

Fig. 6 Technological inventions 
2. Human-related constraints

3. Expertise and knowledge barriers

4. Market-related obstacles

5. Financial and risk-related barriers

United Nations Conference on Trade and Development (UNCTAD) encourages developing countries to integrate technology while diversifying their economic bases by learning and applying various existing technologies. The majority of developing countries technological systems are poor and prone to systemic failures and structural weaknesses, according to the report [40]. According to Ms. Sirimanne, developing countries also should connect their science, technology, and innovation policies with their industrial policies. "New technologies have the potential to revitalize conventional manufacturing sectors, as well as accelerate industrialization and economic structural transformation," she noted. UNCTAD also encourages governments in developing countries to enlist the support of stakeholders who can help in enhancing the connections between the estimated projects, technologies, and other economic policies, including industrial, commercial, administrative, monetary, and educational policies. In addition, the government, commerce, and labor unions should collaborate to maximize the productivity potential of these technologies, especially in developing cities.

\section{The application/empirical study}

The following section will organize the findings of the research according to each section results. Within each section, findings will be structured according to the method used. For example, revitalizing the urban void is one of the significant impacts that raise the vitality of spaces and increase city income, and that is what designers became aware of. Accordingly, the research used studies that link urban voids design components in developing countries, users' needs, and technological installations in rebranding cities, including choice of space function, satisfaction with the users' activities, and return income. Based on the analysis of studies that used questionnaires and interviews with users, developers, and designers, and content analysis of space form that is likely to have impacts on branding the city, maybe grouped into three main dimensions: (1) urban voids design components, (2) users, and (3) technological installations. These could be further elaborated into the 32 elements presented in Table 4.

There are four main steps to follow to engage these voids with the city urban fabric and contribute to a better quality of life. Moreover, using new technological installations enhances space quality, saves energy, and increases project income. The four steps are prequalification survey and goal setting, (2) site analysis, (3) the relation between the indicators and space considerations, and (4) applying the revitalization plan.

\section{Location and context}

\section{Why are new cities selected?}

Many urban theories have emphasized the significance of urban voids in the city. According to Trancik [15], every new city has vacant or undefined spaces in enormous numbers because of the ill-design and planning approaches that produce undefined spaces which turn into wasted spaces [15], see Fig. 7. 


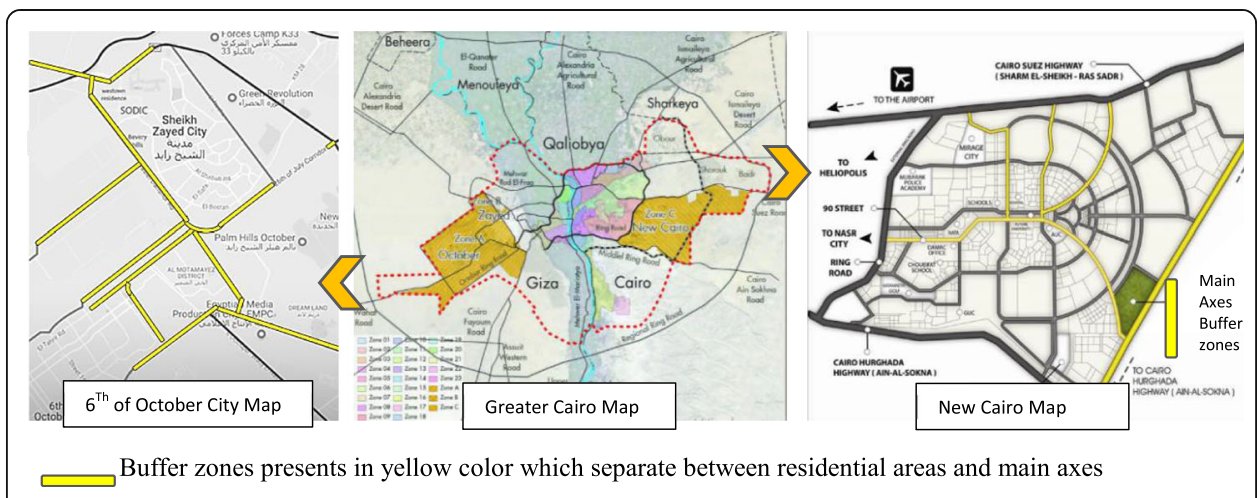

Fig. 7 Map presents greater Cairo with the 2 main poles of new communities (6th of October City and New Cairo). Buffer zones presents in yellow color which separate between residential areas and main axis

\section{Why 6th of October City?}

6th of October city-a new city in the desert-is a city in Giza Governorate, a satellite town and part of Cairo, Egypt. The settlement established in 1979, and it was announced as the capital of 6th of October Governorate in April 2008. The city is one of Egypt's major industrial zones, which serves as the foundation for the entire city. It is accompanied by a banking sector that brings together branches of all Egyptian banks. Also, there are many private universities and schools. The 6th of October City is the first new city built to solve urban problems, utilize untapped resources, reconstruct the capital's high population, face fast urbanization, and entice migration. To address all of these issues, the development of new cities remains the best option [41].

In terms of planner's perspectives, all interviewees agreed that 6th of October is one of Egypt's relatively more prosperous cities. A lot of things contribute to this relative performance. They are (a) the location within the capital region, where so much of the city's economic activity takes place, (b) the preferred target for large financial assistance public housing programs, (c) a major industrial zone with both public and private factories benefiting from significant incentives, and (d) the attractiveness for flagship public and private investments and iconic brands [43].

A great development happened in 6th of October City lately, and its boundaries were extended, presented in the map in Fig. 8. The city offers a wide range of educational, residential, and entertainment activities like shopping malls, cinemas, clubs, and other activities. On the other hand, there were many leftover spaces without beneficial uses. These spaces were neglected for many years. Most of these urban voids were buffer zones that separated the residential communities from the central axis roads. Recently, many projects were constructed in these voids and became a trend in the city which revitalize these spaces and the city as a whole.

\section{Buffer zones voids analysis in the city}

As mentioned before, there are different urban voids in 6th of October City like buffer zones, parking lots, and under-flyovers. The study will concentrate on urban buffer zones typology as it is the most common type in the city, and also the most common projects were built in these voids. In the 1980s, 6th of October City was built based on creating an attractive pole for the urban community that affords a new place to live 


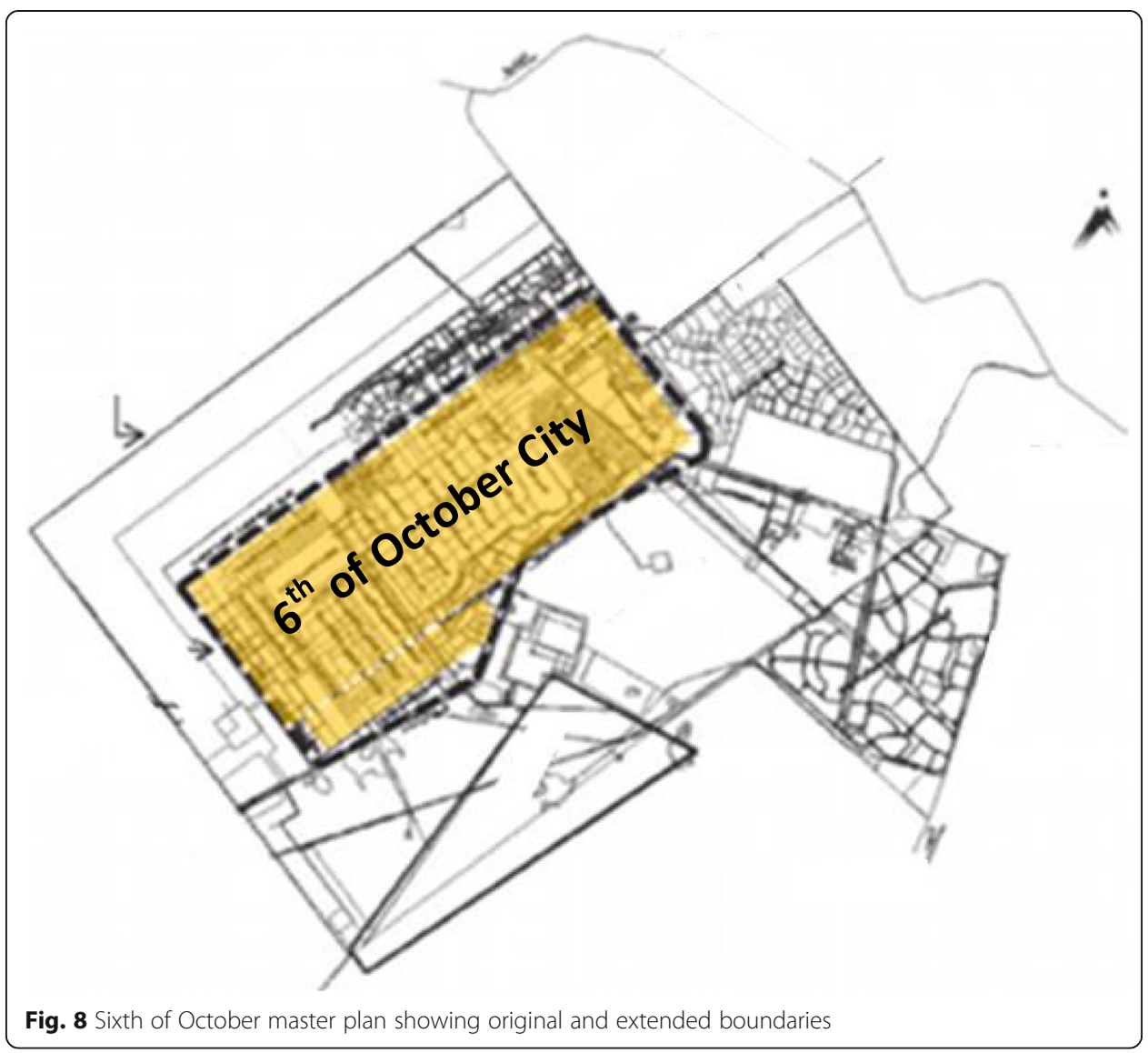

away from the downtown. Figure 9 presents the most common urban voids: buffer zones in 6th of October City, deserts, parking lots, or green spaces.

Revitalizing the urban voids by generating new activities and greening spaces instead of leaving a neglected and undersigned space. The previous map points out the spaces that come under this category of spaces among built structures. The spaces have been identified as "Edge and Buffer zones" due to their spatial design. A selection criterion was followed to identify these voids.

\section{Selecting the area of study}

In the last 3 years, there has been a revolution in developing urban voids on the central road axis like the 26th July corridor (The Strip and The Green Park), and Dahshour Corridor (ZAP and other projects) (Fig. 10). The choice of these spaces is based on the typology of the urban void-buffer zone-and the new activities that appeared in these zones. So, The Strip on 26th July axis and ZAP on Dahshour corridor was the almost completed project, and they reflect two different levels of projects.

The Strip, 26th July axis, contains different types of cafes and on-the-go shops targeting the passer pay users and youth. Therefore, it affords easy access to users and different facilities. On the other hand, there were different type of restaurants and cafes in ZAP project, in Fig. 11, which were designed in a different way as it contain a path for walking and another one for bicycles. Also, the developer make a priority for the kids 


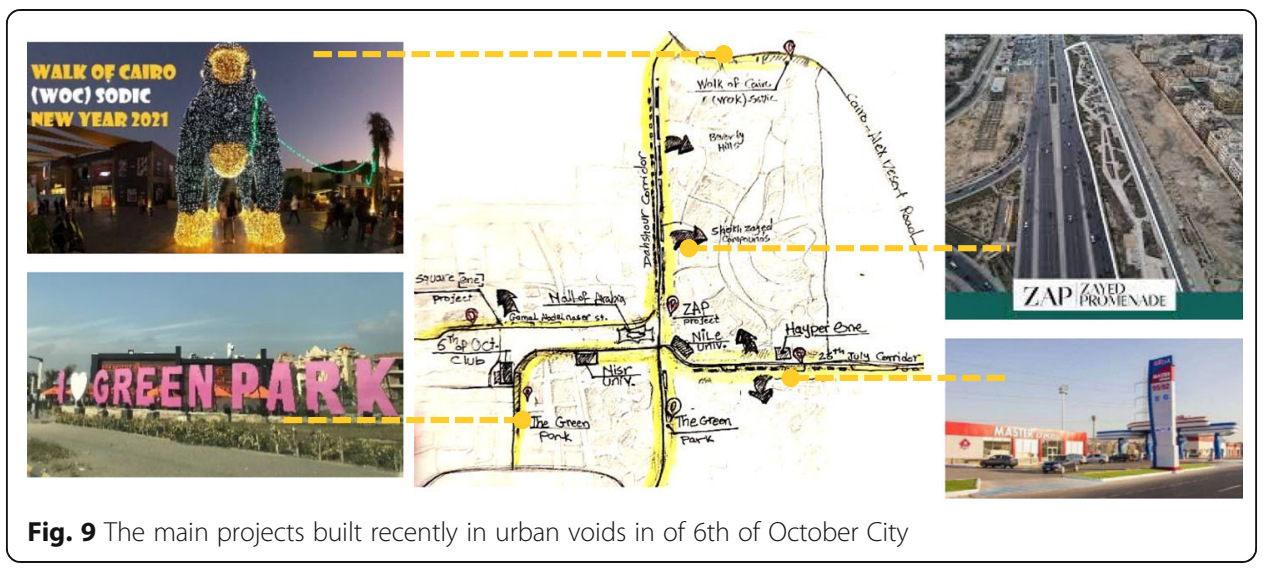

even in safety and designed a playground for them to enjoy which encourage families to use the space more than others. Moreover, the space filled of green spaces and seating areas which integrated together in a good way.

From this point of view, the research focused on analyzing the current situation for both projects to determine the advantages of these spaces and their reflection on the city life and the disadvantages and how to deal with it. All of that will be proposed in a framework that explains the importance of revitalizing urban voids and its impact on city income.

\section{Urban voids revitalization stage}

The reuse and revitalization of urban voids directly affect rebranding cities and increasing city income, as it is one of the significant impacts that designers became aware of. Accordingly, the research used studies that link urban voids design components in developing countries and using technological installations to revitalize urban voids and increase their values, including choice of space, satisfaction with the living context, and users' behaviors. Based on the analysis of studies that used questionnaires with residents, developers, and designers, and content analysis of marketing material—the "design elements" of urban voids that are likely to have impacts on city income may be grouped into three main dimensions: (1) urban voids design components, (2) users of the space, (3) technological installations and their applications on different elements of urban public space. Then, the relationship between the three main factors affecting the space "space design

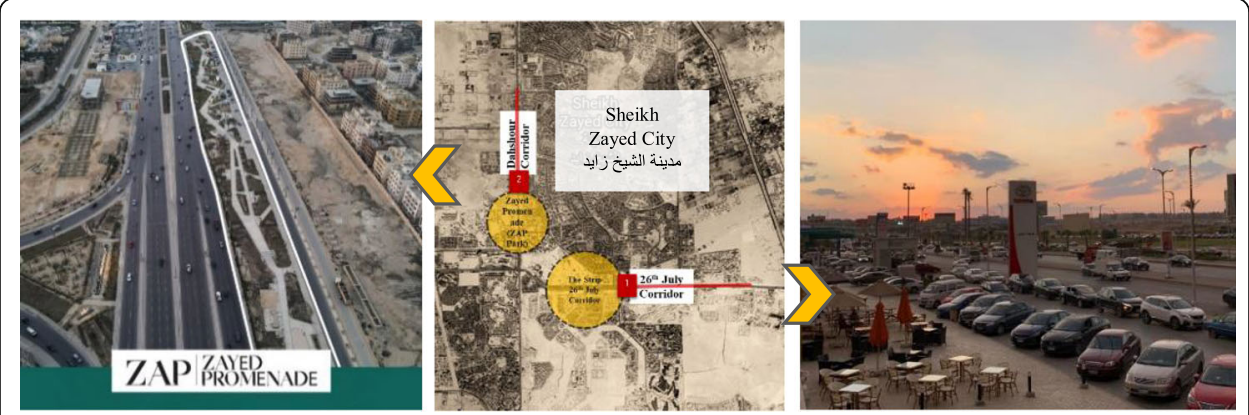

Fig. 10 6th of October urban voids revitalization projects ZAP and The Strip Projects 


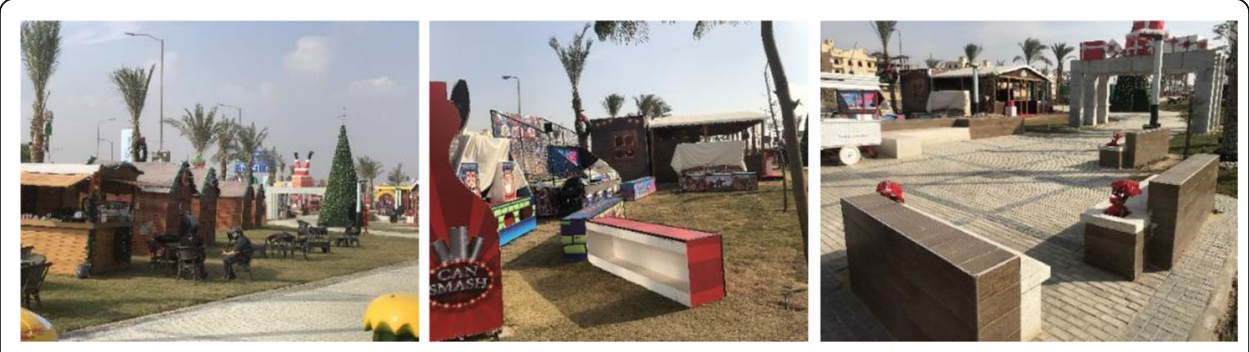

Fig. 11 ZAP Project-Dahshour corridor presenting the cafes, kids area, and seating zones

components," "users," and "technology" and the design considerations to revitalize urban voids in selected spaces. These could be further elaborated into the 32 elements presented in Table 4.

\section{Urban voids questionnaire formulation stage}

The research deployed the three extracted and presented elements in revitalizing urban voids which are previously discussed. It is related to each of the extracted design elements of urban voids spaces to its detailed design components related those elements to users' needs and the used technology in the space. A questionnaire undertaken with practitioners in the design of urban spaces. So that, to have reliable answers to the questions related to design components, users' needs and technological installations in revitalizing urban void spaces, respondents should combine knowledge and theoretical background in the addressed aspects and issues.

Accordingly, the research depended on collecting the answers from "academic" practitioners, experts, and users of the space. The questionnaire distributed among practitioners and faculty members is presented in Table 3, with various specializations in

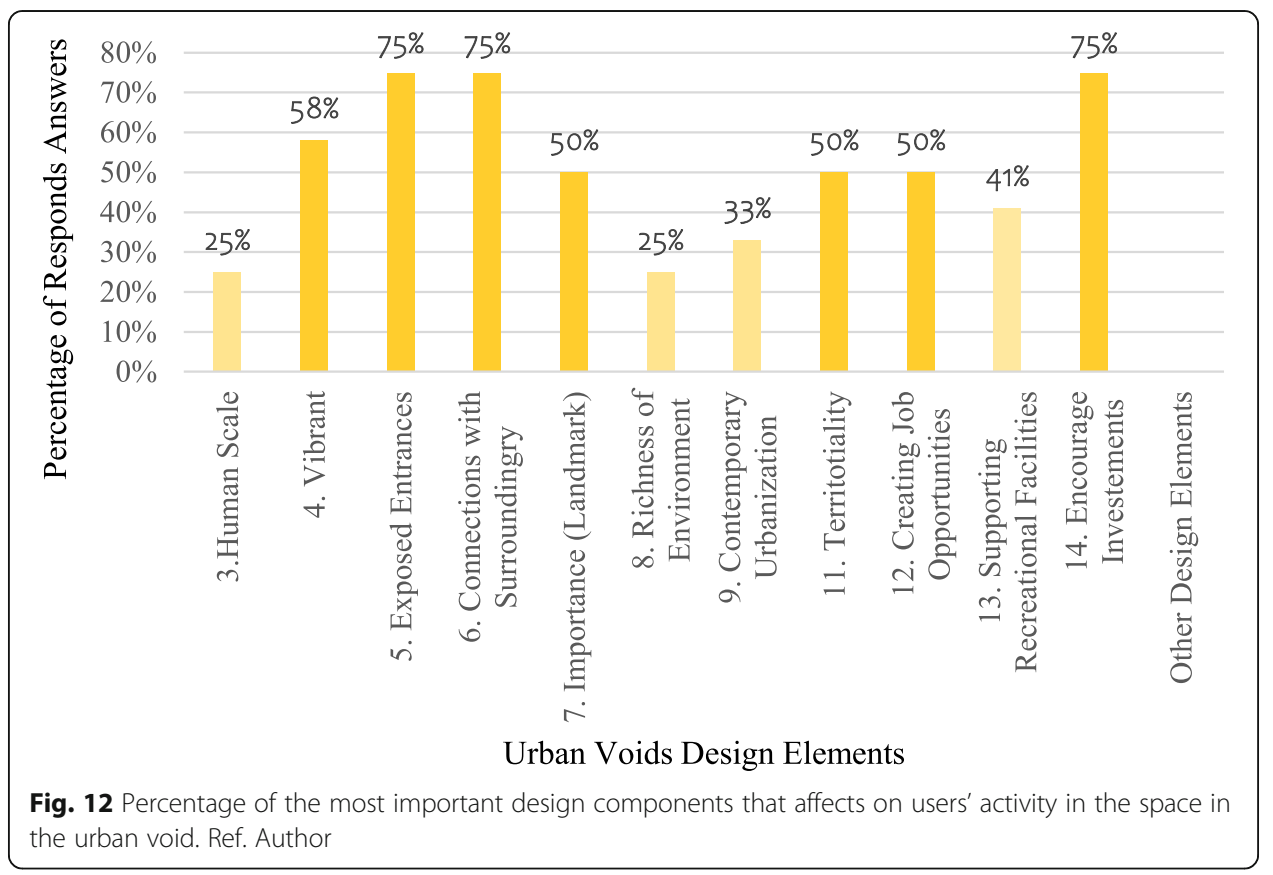


Table 3 The sample selected from practitioners and academics in the questionnaire

For Architects and Experts

\begin{tabular}{|c|c|c|c|c|c|}
\hline Name & & & & & \\
\hline \multirow{2}{*}{ Age } & $20-30$ & $30-40$ & $40-50$ & $50-60$ & Above 60 \\
\hline & 2 & 2 & 2 & 2 & 2 \\
\hline \multirow{2}{*}{ Gender } & \multicolumn{2}{|c|}{ Male } & \multicolumn{2}{|r|}{ Female } & Total \\
\hline & \multicolumn{2}{|c|}{6} & \multicolumn{2}{|r|}{4} & 10 \\
\hline \multirow{2}{*}{ Years of Experience } & 5-10 Years & 10-15 Years & 15-20 Years & 20-30 Years & $>30$ Years \\
\hline & 2 & 2 & 2 & 2 & 2 \\
\hline \multirow{2}{*}{ Nationality/ Belonging } & Egyptian & & Arabian & & Non- Egyptian \\
\hline & 10 & & - & & - \\
\hline \multicolumn{6}{|l|}{ For Users } \\
\hline \multicolumn{6}{|l|}{ Name } \\
\hline \multirow{2}{*}{ Age } & $18-25$ & $25-35$ & $35-45$ & $45-60$ & Above 60 \\
\hline & 3 & 3 & 3 & 3 & 2 \\
\hline \multirow{2}{*}{ Gender } & \multicolumn{2}{|c|}{ Male } & \multicolumn{2}{|r|}{ Female } & Total \\
\hline & \multicolumn{2}{|c|}{8} & \multicolumn{2}{|r|}{6} & 14 \\
\hline \multirow{2}{*}{ Marital Statues } & \multicolumn{2}{|c|}{ Single } & \multicolumn{2}{|r|}{ Married } & Have Children \\
\hline & \multicolumn{2}{|c|}{5} & \multicolumn{2}{|r|}{3} & 6 \\
\hline \multirow{2}{*}{ Nationality/ Belonging } & \multicolumn{2}{|l|}{ Egyptian } & \multicolumn{2}{|l|}{ Arabian } & Non- Egyptian \\
\hline & 12 & & 1 & & 1 \\
\hline
\end{tabular}

practice and research. Answers obtained from 24 respondents whose mean of experience in designing urban public spaces ensure reliable responses supported by users' responses.

On the other hand, these questionnaire was applied in different ways, some of them were online, and the others were answered through interviews which assist in getting more about users' experiences in these revitalized voids, getting more information about the advantages and disadvantages of these type of projects built in buffer zones. This process took a long time to cover each point in the questionnaire and to improve its final form.

\section{Urban voids design revitalization elements and economic values: preliminary matching}

The research deployed the importance of urban voids revitalization. The questions were selected for the practitioners to get the most efficient design component related to users' needs and activities in the space and, accordingly, the technological installations that used to revitalize such voids and their impact on them. This methodology was followed to build up a questionnaire that asked architects and users of these revitalized voids about their experience with each design component and revitalization actions that helped or hindered their experience in the space. Each question was formulated by matching the "design components" respective to each "users' activities" taking in consideration the technological systems used in the revitalized urban void.

The questionnaire included three main design principles that combined to generate a framework to be used as a guideline while reusing and revitalizing urban voids, namely, urban voids design components, users' needs and activities, and technological 
Table 4 Model formulation-levels of the contribution of "urban voids design components," "users' needs" and "technological installations" to urban void revitalization framework to its "economic value" in revitalizing and rebranding cities (ref. Author)

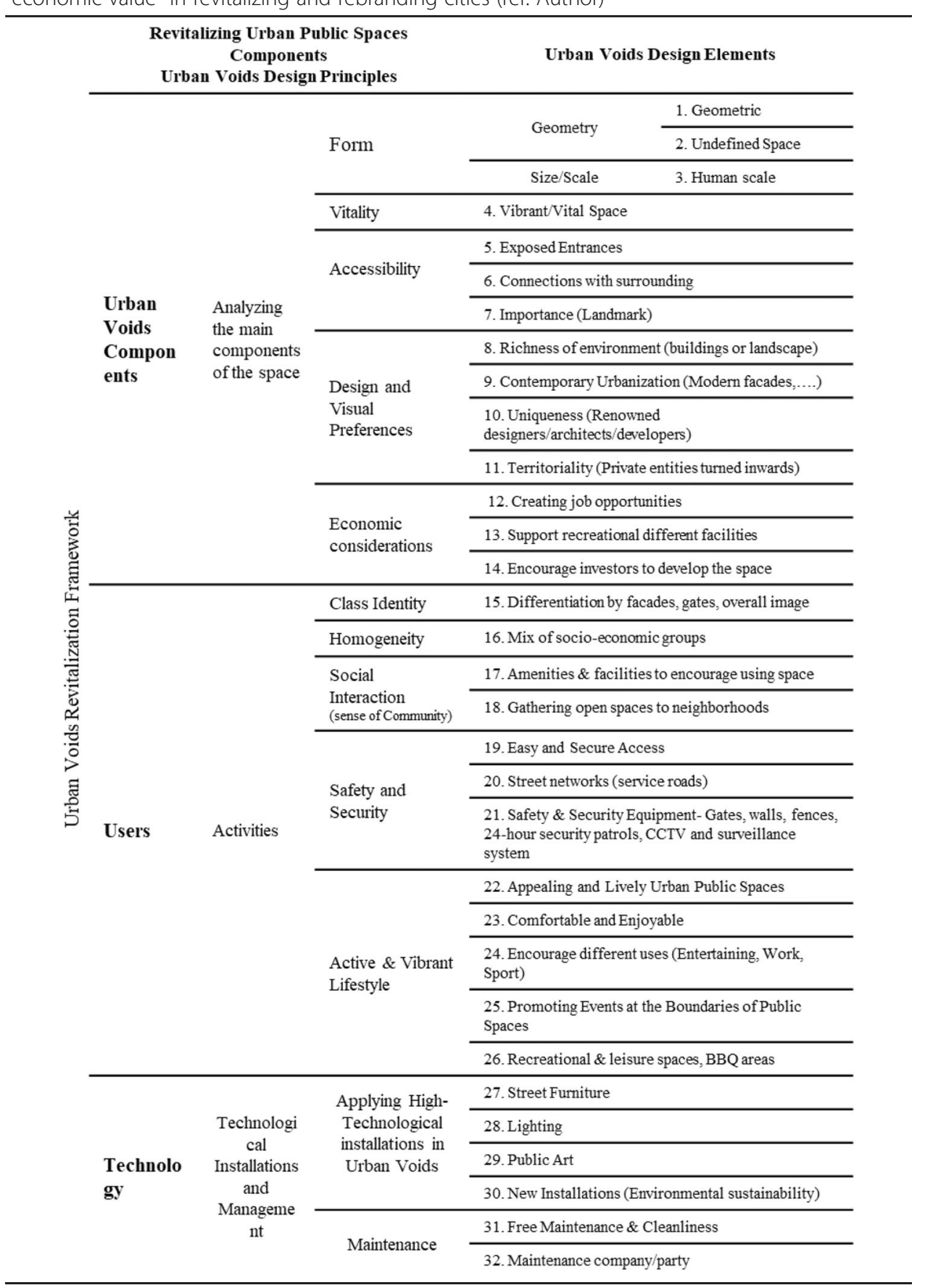

installation (Table 4). The questions were rephrased in each question to be quickly answered and completed, using a 5-point Likert scale, presented in Table 4. The second part was an interview with architects and users of the space. They were asked about which components of the space encouraged them to choose this space without any other space and also the missing components that users needed to be added. It is essential to empower citizen's participation as they are the future users of these 
revitalized spaces. In addition, the horizontal cooperation of all stakeholders at all levels and vertical coordination across government entities to ensure that resources are used efficiently and effectively [41].

In the questionnaire and interviews, the respondents were asked to define the urban space generally and describe its form according to their experience. They were asked to grade the five design components importance. These components are form, vitality, accessibility, design and visual preference, and economic considerations. This part aimed to know to which extent that users' understand and are satisfied with the space performance agreed with the actual data of the project and if the technological installations affect the space directly and in its revitalizing process. Also, the questionnaire asked respondents to grade the contribution of each of the 32 elements in its respective urban voids revitalization framework.

\section{Analytical study/results and discussion}

According to the problems defined during the research in the study area, there are some suggested points to reuse and revitalize the urban voids' overall condition and provide a good image that is presently unavailable there. Of course, these are not the only possible components for revitalizing urban voids, but they present the most common and affordable components to improve the availability and afford an acceptable range of practical options. One of the most important approaches is to apply the recommended urban voids design components, achieving users' needs and integrating technological installations through revitalizing the space.

The cooperation between these three main parts will lead to a successful revitalization framework, which is concluded in a matrix presented in Table 5. First, the horizontal row named urban voids design components sector, presenting $14 \mathrm{com}$ ponents from 1 to 14 . These components will assist in making decisions, primarily when they are related to design decisions and financial and funding issues. Second, users' needs and activities, the vertical column, presenting the most important 12 elements in this sector from 15 to 26 . These elements are the dynamo of the revitalization process. They are also the future users of these spaces and the creative body of the revitalization process. Third, technological installations will be linking the previous two sectors to each other, responsible for emerging new systems if needed, and balancing all parts involved in the process to increase space efficiency and be up to date.

After analyzing the data gathered from site visits, surveys, questionnaires, and interviews, the main design components directly impact users' needs and activities in various approaches presented in dark yellow color. On the other hand, other components have less impact on users, highlighted in light yellow color. Moreover, some components used technological installations to achieve users' needs to increase space efficiencies like interactive installations, smart furniture, new lighting systems, and interactive public art.

The questionnaire's results revealed that "exposed entrances" and "connections with surrounding" are the essential factors. These two elements were the most chosen (elements 5 and 6 in Table 4). They scored the highest results. After that, "vital/vital space" and "encourage investments" (elements 4 and 14 in Table 4), they scored the next highest score of the respondents choice, compared to the following essential design components like elements 7, 11, 12 that scored the third highest scores. 
Table 5 Urban voids (buffer zones) framework based on studies and respondents answers representing the impact of applying design components on users' activities and technological installation (T) used in urban void spaces (ref. Author)

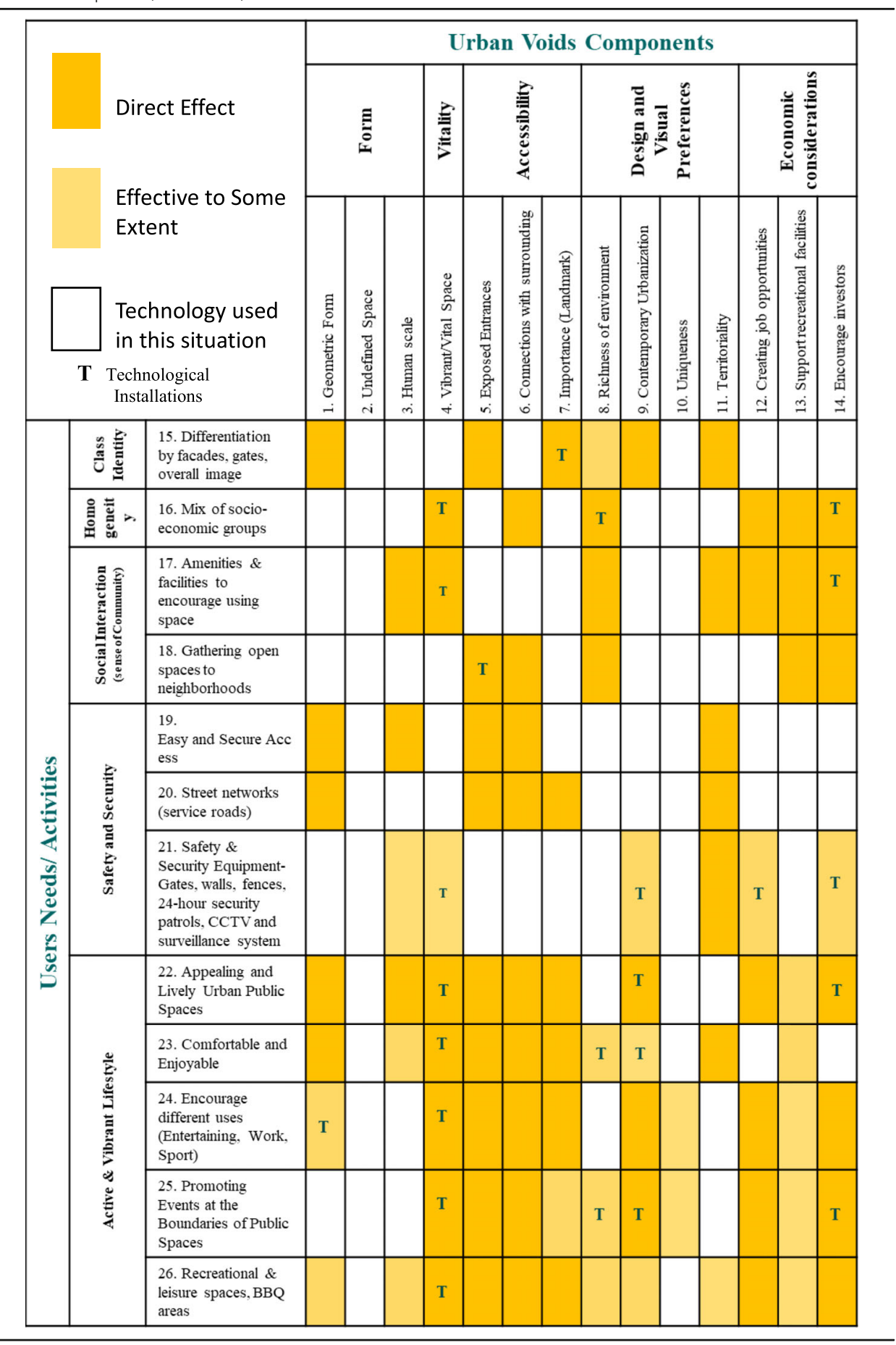

Moreover, elements that had a less impact on achieving users' needs were elements 3, 8, 9, and 13 in Table 4; leaving other design components with a lower percentage. This resulted in 32 elements that were reasonably agreed upon to the potential of following urban voids revitalization framework and its economic impact on the cities. These results concluded stage 2 of the model formulation presented in Tables 4 and 5 . 
So, urban voids have excellent advantages that should be seen as huge potential and opportunity for the city development and residents quality of life. Furthermore, due to its importance and benefits for the economic development program are also recognized as a potential resource. See Fig. 12.

On the other hand, some disadvantages appeared while dealing with these voids, most of (1) the users complain that there are no safe boundaries for kids away from cars and (2) the lack of kids areas to entertain them in the space. Moreover, (3) the residents of the compound of 26th July corridor complain that the back yard of these projects was unclean. All the services were (4) exposed to their apartments, which annoyed them visually and hygiene-wise. However, these five problems did not appear in Dahshour corridor as the project's typology was designed at a high level and was well maintained.

\section{According to the findings, efficient revitalizing of urban voids}

6th of October urban voids revitalization strategy challenged with economic issues, and its outcome has been challenged for its users' needs, repetitive scenery, land use efficiency, and other issues. Aside from that, technological innovation should be considered as they develop to prepare for our future.

- A clear vision and appropriate strategies for developing urban voids as part of integrated urban development plans

- The public sector should connect all groups and develop new policies to balance all parties involved in the process.

- Using technology nowadays is a must to achieve the most benefits of the space

- Flexible planning system with some areas susceptible to unexpected events. The design of urban voids is a continuous process that does not end with the implementation phase

- Maintenance is an essential issue to keep the project in good condition.

\section{Conclusions}

The study provides comprehension of the meaning of urban voids and the processes in which they arise, and the detrimental impact of existing urban voids on city quality of life, based on a review of literature studies about urban voids. Also, the study presents urban voids as a value, concluding that the revitalization of urban voids can provide social and economic values by performing a variety of ecosystem, functions, including using new technological installations in urban voids as green infrastructure, improving air quality, preserving natural habitat, and producing renewable energy. Moreover, these voids can also provide economic value by being repurposed as a small local business, which can help with economic regeneration by providing temporary uses, improving the property's value and surroundings, and offering work possibilities through small-scale enterprises. Revitalizing urban voids while embracing the city history and identity enhances historical and cultural value by enhancing the city identity and character and promoting cultural activities and education. Enhancing urban voids in imaginative, appealing ways improves the city's esthetic look and establishes a solid urban fabric. 
Through a theoretical study and analysis of existing project that have experimented with the reuse of urban voids, as well as an evaluation of the positives and negatives of such projects, the study explained the meaning of vacant spaces and how they are formed, shed light on the importance of vacant spaces as a resource, and explore their environmental, social, economic, cultural, and esthetic values and benefits. Also, through the theoretical study and analysis of lessons learned for a set of experiences, it proposes a guiding revitalization framework to guide designers and planners to develop a method of reusing and developing vacant spaces to maximize their values and benefits. The study concluded that the efficient use of vacant spaces requires considering them as an integrated part of the city's urban fabric through coordinating cooperation between all parties involved in the development process to revitalize the voids, rebrand, and increase city income.

Abbreviations

ECOTECHNOLOGY: Ecology + Technology; UNCTAD: United Nations Conference on Trade and Development

\section{Acknowledgements}

Many thanks to my family: dad, mom, husband, and dear daughter Laila for their support.

\section{Authors' contributions}

$\mathrm{TI}$ explained the meaning of urban voids typologies and its value. SW analyzed and interpreted the urban voids potentials regarding the developing countries and its economic impact. OM collected the data of the case study and analyzed it, and was a major contributor in writing the manuscript.

All authors OM, SW, and TN worked together in the all research process and they have read and approved the manuscript.

\section{Funding}

This study had no funding from any resource.

\section{Availability of data and materials}

The datasets generated during and/or analyzed during the current study are available in the [Omnia Mamdouh] repository. The datasets used and/or analyzed during the current study are available from the corresponding author on reasonable request.

\section{Declarations}

Ethics approval and consent to participate

Not applicable.

\section{Consent for publication}

Not applicable.

\section{Competing interests}

The authors declare that they have no competing interests.

Received: 22 July 2021 Accepted: 24 November 2021

Published online: 14 January 2022

\section{References}

1. Seog Jeong Lee SH (2015) True smart and green city? Urban voids: as a chance for sustainable urban design. Proceedings of the $8^{\text {th }}$ Conference International Forum on Urbanism

2. Thawaba S, Ballout T, Morcos Y (2016) Revitalizing urban voids by using GIS. Birzeit University, Research Gate, Lebanon

3. Kasarabada D (2020) Urban leftovers: identifying and harnessing their potential for the agenda 2030 in Malmö. Malmo University, Scania

4. Fracasso Y-S (2015) Urban voids unpacked. Institute of Architecture \& Design, Aalborg University, Denmark

5. Feehan, D. \& (2006) Making business districts work: leadership and management of downtown, main street, business district and community development organizations. Haworth Press, New York

6. Miller KF (2007) Designs on the public: the private lives of New York's public spaces. University of Minnesota Press, New York: Minneapolis

7. Im Sik Cho CK (2016) Re-framing urban space: urban design for emerging hybrid and high-density conditions. Routledge: Taylor \& Francis, New York

8. François Jégou, M. B. (2016). Refill reuse of vacant spaces as driving force for innovation on local level, state of the art. Refill Urbact III.

9. Lynch K (1981) A theory of good city form. MIT Press, Cambridge

10. Seçil ŞATIR, E. K. (2005) Urban open spaces with examples \& the classification. TURKEY: ITU A|Z 
11. Tonnelat S (2010) The sociology of urban public spaces. Atlantis Press, Paris

12. Friedmann J (2010) Place and place-making in cities: a global perspective. Planning Theory \& Practice 11(2):149-165. https://doi.org/10.1080/14649351003759573

13. Mandeli KN (2010) Promoting public space governance in Jeddah, Saudi Arabia. Cities 27(Issue 6):443-455

14. Hanzl M (2013) The meaning of public spaces. Taylor \& Francis Group, Poland

15. Trancik R (1986) Finding lost space: theories of urban design. John Wiley and Sons, INC., Canada

16. Bravo L (2013) Open spaces, public spaces, publics, open-minded places. Italy: the public space of education

17. Nefs, M. (2006). Unused urban space: conservation or transformation? Polemics about the future of urban wastelands and abandoned buildings. City \& Time 2. Retrieved from http://www.ct.ceci-br.org.

18. Belete T (2010) Development of urban vacant land the case of Addis Ababa-along ring road from Bole Square to Megenagna Square. Thesis Master of Science in Degree of Urban Design and Development, Addis Ababa

19. Lynch K (1981) The image of the city. The M.I.T. Press, Massachusetts Institute of Technology, Cambridge, Massachusetts, and London, England

20. Abdel Rahman A (2016) Redevelopment aspects for brownfields sites in Egypt, pp 25-35

21. Cirik U (2005) A design problem of under-utilized spaces: the case of Ankara-old industrial district. A thesis submitted to the graduate school of natural and applied sciences of Middle East technical university

22. Rathi K (2016) Urban Voids - adaptive use of public spaces under flyovers. School of Architecture, IPS Academy Indore, India

23. Wroblewski W (2015) Urban voids as communication gaps envisioning architecture: image, perception and communication of heritage. Lodz University of Technology, pp 466-474

24. Nermeen Ali Omar EH (2019) Urban voids as potential resources for the city development. J Eng Sci 47(5):585-600

25. James Goldstein MJ (2001) Urban vacant land redevelopment: challenges and progress. Lincoln Institute of Land Policy Working Paper, Boston

26. Ghadban LN (2015) In-between forgotten spaces in Palestinian cities: the twin cities of Ramallah and Al-Bireh as a case study. The Sustainable Development and Planning. WIT Transactions on Ecology and the Environment, vol 193

27. Heike Rahmann \& Jonas, M. (2013). Void. Interstitial practices of doubt and reward.

28. Kabir, S. \&. (2015) Innovative use of space underneath a flyover of Dhaka THAAP Journal: Culture, Art \& Architecture of the Marginalized \& the Poor. Culture, Art \& Architecture of the Marginalized \& the Poor

29. Rathi NK (2017) Urban voids - reclaiming urban space. Int J Adv Res Ideas and Innov Technol 3(Issue 1):196-203

30. Elrahman AA (2016) Redevelopment aspects for brownfields sites in Egypt. Egypt: Procedia Environmen Sci 34:25-35

31. New Urban Communities Authority (2021), from http://www.newcities.gov.eg/.

32. Jackson JB (2006) Brownfields - the need for policy, startegy and an institutional framework. Brownfields III: Prevention, Assessment, Rehabilitation and Development of Brownfield Sites. WIT Transactions on Ecology and the environment, vol 9

33. Governement, V. S. (2016). Urban design guidelines - public spaces. Retrieved July 14, 2020, from https://www.urbandesign-guidelines.planning.vic.gov.au/guidelines/public-spaces

34. FBRA, F. B (2007) Florida brownfields redevelopment program. Department of Envirnmental Protection, Florida

35. Columbia, B. (2014). A community resource guide for brownfields redevelopment: case studies. B.C. Brownfield renewal.

36. Zárate Martin MA (2005) Geografía humana, sociedad, economía. Madrid, Spain

37. Ferber, U. \&. (2006) Brownfields handbook: cross-disciplinary educational tool focused on the issue of brownfields regeneration. Lifelong educational project on brownfields. Leonardo da vinci pilot project. The European commission

38. Mina Khodadad MS (2017) Necessity of collaboration between technology and architectural design in order to develop the urban space quality. Scientific Research Publishing Inc.: World Journal of Engineering and Technology

39. Blouin GA (2020) Barriers to the adoption of green building materials and technologies in developing countries: the case of Burkina Faso. USA: IOP Conference Series: Earth and Environmental Science

40. UNCTAD. (2021). A few developing countries overperform on frontier technologies, but most lag behind. Retrieved from https://unctad.org/news/few-developing-countries-overperform-frontier-technologies-most-lag-behind

41. Elrahman AA (2015) Redevelopment aspects for brownfields sites in Egypt. Improving Sustainability Concept in Developing Countries. Department of Urban Design and Planning. Ain Shams University, Cairo

\section{Publisher's Note}

Springer Nature remains neutral with regard to jurisdictional claims in published maps and institutional affiliations.

\section{Submit your manuscript to a SpringerOpen ${ }^{\circ}$ journal and benefit from:}

- Convenient online submission

- Rigorous peer review

- Open access: articles freely available online

High visibility within the field

- Retaining the copyright to your article

Submit your next manuscript at $\boldsymbol{\sim}$ springeropen.com 